\title{
СТУПЕНІ ПОРІВНЯННЯ ПРИКМЕТНИКІВ: ВІД ПОРУШЕННЯ НОРМИ ДО ТРАДИЦІї (на матеріалі словника А. Нелюби, Є. Редька Словотворчість незалежної Украйни. 2012-2016)
}

\author{
ОКСАНА ХАЛІМАН \\ Харківський національний педагогічний університет імені Г. С. Сковороди, \\ Харків - Україна \\ khaliman_oksana@ukr.net; ORCID: 0000-0001-6952-0627 \\ FORMY STOPNIOWANIA PRZYMIOTNIKÓW: \\ OD ODSTEPSTWA OD NORMY DO TRADYCJI \\ (na materiale słownika A. Neluby i J. Red’ki \\ Stowotwórstwo niepodległej Ukrainy. 2012-2016) \\ OKSANA CHALIMAN \\ Charkowski Narodowy Uniwersytet Pedagogiczny imienia Hryhorija Skoworody, \\ Charków - Ukraina
}

STRESZCZENIE. W artykule opisano tendencje tworzenia form komparatiwu i superlatiwu we współczesnym języku ukraińskim na materiale słownika A. Neluby, J. Red ki Słowotwórstwo niepodległej Ukrainy. 2012-2016 (2017). Modele tworzenia form od przymiotników jakościowych oznaczających cechę niestopniowalną, dzierżawczych, przymiotników złożonych itp. sprzyjają reinterpretacji, rozszerzeniu struktury semantycznej słów podstawowych. Cechuje je regularność. Podkreślono potrzebę usystematyzowania odpowiednich tendencji z uwzględnieniem ich regularnej odtwarzalności w gramatyce języka ukraińskiego, ujęciem i objaśnieniem nowych odcieni semantycznych w źródłach leksykograficznych.

Słowa kluczowe: przymiotnik, komparatyw, superlatyw, gramatyka, słownik, język ukraiński.

\author{
DEGREES OF COMPARISON OF ADJECTIVES: \\ FROM NORM VIOLATION TO TRADITION \\ (based on dictionary compiled by A. Neliuba, Ye. Redko \\ Word-Formation in Independent Ukraine. 2012-2016)
}

\section{OKSANA KHALIMAN}

H. S. Skovoroda Kharkiv National Pedagogical University, Kharkiv — Ukraine

ABSRACT. The article focuses on the tendencies description of the comparative and superlative forms in modern Ukrainian based on the dictionary compiled by A. Neliuba, Ye. Redko Word-Formation in Independent Ukraine. 2012-2016 (2017). The formation models favour the reinterpretation, enlarge the semantic structure of the initial words from qualitative adjectives, which nominate non-grade characteristics, from relative, compound adjectives, from nouns with the omission of the adjectivity stage, the inclination to the synthetic forms. These formation models are marked with regularity. The need to codify the correspondent tendencies, taking into account the regularity of reproduction in the Ukrainian language grammar books sources has been argumented, as well as the need to fixate and interpret new semantic shades in lexico-graphic sources.

Key words: adjective, comparative, superlative, grammar, dictionary, Ukrainian language. 
$\mathrm{B}$ ажливою ознакою літературної мови є ії стійкість, проте мова, як кожний живий організм, розвивається, збагачується, удосконалюється. Цей процес представники Празького лінгвістичного гуртка назвали “гнучкою стабільністю", а українські лінгвісти (С. Єрмоленко, О. Тараненко, Л. Струганець та ін.) - динамікою мовної норми. Засобами подібних змін часто стають аномальні випадки функціювання мовних одиниць. Ю. Апресян назвав їх “мовними аномаліями", що кваліфікуються “як точки росту нових явищ"2.

Мовні аномалії - це значний пласт у реалізації кожної мови, прикладом чого можуть слугувати як високохудожні твори, так і звичайні повсякденні мовленнєві помилки, де ненавмисне чи мотивоване порушення норми створює відповідні прагматичні ефекти. Помилка виникає на межі мовної зміни й може покласти початок тенденції варіативності мовних явищ. На це звертає увагу й Т. Космеда, зауважуючи, що „живе мовлення рухливе, змінюване, не завжди схвалюється офіційною нормою - незвичний наголос, оказіональне слово, моделювання нового змісту, синтаксичний зворот, не передбачений граматикою, проте можна навести масу прикладів, коли факти мовлення стають фактами мови"'. Про це писав і Л. Щерба. Він наводив приклади мовленнєвих уживань, наголошуючи, що незабаром вони можуть стати нормативними.

„Норма й аномалія, - як стверджує Н. Арутюнова, — не розділені глухою стіною"4. В основі навмисних мовних аномалій - внутрішні, “природні" властивості самої мови - ii будови й функціювання"5, тобто ці порушення не безсистемні й випадкові, а теж відбуваються за певними правилами, мають відповідні закономірності. Безперечно, „користь порядку очевидна, користь відхилень від норми потребує обгрунтування”. Нове не первинне: воно „завжди відсилає до прецедента"7. Так виникають „правила для порушення правил й аномалії, необхідні для розуміння норми" ". Проблему мовних девіацій, помилок та їхню прагматичну сутність сьогодні розробляють такі відомі науковці, як Ю. Апресян, Ф. Бацевич, Т. Булигіна, І. Кобозєва, Т. Космеда, О. Кубрякова, О. Кукушкіна, Н. Лауфер та ін.

Граматика не меншою мірою, ніж лексика відзначається значними ресурсами в плані аномальної актуалізації мовної системи як вияв іiі креативності. У сучасній граматиці „виникла необхідність характеристики креативних інтерпретацій граматичних одиниць, що дасть змогу доповнити відомі описи граматичної системи української мови й, очевидно, пояснюючи закони інтерпретацій граматичних одиниць, фіксуючи зародження нових форм і нових явищ, певною мірою спрогнозувати їхній розвиток"я. О. Ремчукова серед чинників, що харак-

${ }^{1}$ Н. Ф. Клименко, С.А.Карпіловська, Л. П.Кислюк, Динамічні процеси в сучасному українському лексиконі, Київ 2008, с. 381.

${ }^{2}$ Ю. Д. Апре сян, Избр. тр., в 2 томах, Москва 1995, т. 2, Интегральное описание языка и системная лексикография, с. 64.

${ }^{3}$ Т. А. Космеда, Лингвокалейдоскоп: процессы живой речи (на материале русского и украинского языков), Саарбрюккен 2017, с. 9.

${ }^{4}$ Н. Д. Арутюнова, Аномалии и язык (к проблеме языковой “картины мира”), [в:] „Вопросы языкознания”, 1987, № 3, с. 3.

${ }^{5}$ Б. Ю. Норман, Игра на гранях языка, Москва 2006, с. 9.

${ }^{6}$ Н. Д. Арутюнова, указ. источ., с. 4.

${ }^{7}$ Н. Д. Арутюнов а, Язык и мир человека, Москва 1998, с. 725.

8 Ю. М. Лотман, Декабрист в повседневной жизни (бытовое поведение как историкопсихологическая категория), [в:] Литературное наследие декабристов, ред. В. Г. Базанов, В. Э. Вацуро, Ленинград 1975 , с. 26.

${ }^{9}$ Т. А. Космеда, О. В. Халіман, Мовна гра в парадигмі інтерпретативної лінгвістики. Граматика очінки. Граматична ігрема (теоретичне осмислення дискурсивної практики), Дрогобич 2013. 
теризують креативний потенціал граматики, називає розвинуту парадигматику, що передбачає наявність лакун (в узусі) й дає змогу їх заповнювати ${ }^{10}$. Надані мовою потенційні можливості „можуть реалізуватися чи не реалізуватися, а згодом актуалізовані потенції прийнятися чи не прийнятися узусом"”, а причини й наслідки мовних змін, як наголошував В. Матезіус, можливо з'ясувати завдяки ретельному вивченню окремих мов, що дасть змогу однозначно встановити, „які явища в них у ту чи ту добу були стабільними, а які потенційними"12.

Мета цієї наукової розвідки - описати тенденції утворення форм компаратива та суперлатива в сучасній українській мові на основі аналізу матеріалів словника А. Нелюби та Є. Редька Словотворчість незалежної України. 2012$2016(2017)$.

Особливості утворення форм ступенів порівняння прикметників у сучасній українській мові неодноразово ставали об'єктом дослідження українських мовознавців (Г. Вокальчук, О. Жижома, Ж. Колоїз, Д. Рязанцева, Л. Семененко та ін.), які характеризували численні утворення як ненормативне ступенювання, порушення норм, граматичні девіації, оскільки активною тенденцією української мови є утворення форм ступенів порівняння від відносних, присвійних та якісних прикметників, що називають неградуйовану ознаку. Мовці моделюють нові смисли за рахунок певного “нехтування" актуальними мовними нормами, змінюючи формальні традиційні показники, закріплені системою мови.

Ж. Колоїз стверджує, що окремі морфологічні слова мають значно ширші можливості щодо реалізації узуально закріплених за ними морфологічних категорій, і наводить приклади вживань відносних, присвійних та порядкових прикметників, що всупереч морфологічним нормам об' єднуються в градаційні ряди (порівн.: весняний-весняніший; наш - нашіший, перший-першіший) і потенційно здатні замкнути їх (порівн.: найвесняніший; найнашіший). Граматичні модифікації, що репрезентують категорію співвідносної інтенсивності ознаки, на думку дослідниці, постають як відхилення від норми, репрезентуючи своєрідну прагматику оказіональних явищ ${ }^{13}$.

Аналізуючи особливості мовної норми у сфері функціювання українського прикметника, Д. Рязанцева зазначає, що ,автори вдаються до свідомого відхилення від норми для того, щоб досягти певного ефекту й передати за допомогою незвичайного слова додатковий смисл", а ступенювання відносних і присвійних прикметників ,відбувається здебільшого через розширення значення слів та нашарування переносних значень, а також для досягнення певного стилістичного ефекту, підсилення впливу висловлення" 14 . Д. Рязанцева описує механізми породження значення оцінки за допомогою прикметників, використовуючи матеріал словників інновацій А. Нелюби попередніх років (Лексико-словотвірні інновації $(2002,2004,2007,2009,2010))$. Активною тенденцією української мови названа вище дослідниця вважає порушення норми для моделювання оцінного значення шляхом певного “нехтування” актуальними мовними нормами, змі-

${ }^{10}$ Е. Н. Ремчукова, Aспекты и принципы креативной грамматики, [в:] Теоретические проблемы функциональной грамматики, матер. Всерос. науч. конф., Санкт-Петербург 2001, c. $49-54$.

11 Ж. В.Колоїз, Українська оказіональна деривація, Київ 2007, с. 196.

12 В. О. Матезиус, О необходимости стабильности литературного языка, Москва 2003.

13 Ж. В. Колоїз, Украӥнська оказіональна деривація..., с. 119.

${ }_{14}$ Д. Рязанце в а, Порушення норми при ступенюванні прикметників, [в:] „Культура слова", Київ 2011, вип. 74, с. 73-74. 
ну формальних традиційних показників, закріплених системою мови для того чи того морфологічного класу грамем. Зокрема, граматика оцінки "маніпулює" такими потенційними моделями утворення форм ступенів порівняння від відносних, присвійних, порядкових та займенникових прикметників та утворення форм ступенів порівняння від якісних прикметників, що називають неградуйовану ознаку ${ }^{15}$.

Поширеним у сучасній мовній практиці є утворення ступеньованих форм від відносних прикметників, приклади, що ілюструють зазначене явище, знаходимо й у матеріалах досліджуваного словника (книжніший, найвелосипедніший, найдніпропетровськіший, найісторичніший, найкиївськіший, найльвівськіший, найпольськіший). Ступенювання можуть ,зазнавати прикметники, що репрезентують значення темпоральної й локативної атрибутивності, речовинності, ад'єктиви суспільно-політичної й наукової сфер"16, порівн.: Юрка Коха називають “найльвівськішим художником” (Літературна Україна, 20.06.2014)17; Але иеей номер особливий, “найпольськіший”, бо всі 300 сторінок його дихають Польщею (Україна молода, 70/2014) ${ }^{18}$. Отже, помічені дослідниками особливості як відповідна тенденція продовжують активно реалізуватися в сучасному мовленні українців.

Як наголошує Д. Рязанцева, таке формотворення „призводить до певних змін у структурі слова. Відбувається розширення семантичного наповнення слів та звуження їхнього вживання в прямих значеннях, що призводить до нашарування переносних смислів - метафоризації семантики"19, реалізації потенційних значеннєвих відтінків слова. Розглядаючи випадки розширення парадигми прикметників (утворення вищого та найвищого ступенів порівняння від слів, що не можуть їх мати, - железный - железнее), В. Санніков характеризує процес так званого “оякіснення відносних прикметників" у художньому тексті як мовну гру або мовні жарти в морфології ${ }^{20}$. Справді, прикметник із локативним значенням львівський, утворюючи форму найльвівськіший, частково втрачає значення 'той, що у Львові' (не обов'язково знаходиться у Львові), набуває ширших значень: 'той, що найбільше відповідає особливостям Львова', ‘такий, як у Львові', ‘типово львівський', 'львівський до глибини душі' (із пояснень мовців). Отже, розширення семантичної структури цього прикметника зумовлює його використання в нових якісних значеннях, зокрема оцінних, змінює граматичні показники цієї лексеми, проте відповідні позначення в сучасних словниках відсутні.

Як відомо, домінантними в повсякденному функціюванні дослідники вважають синтетичні форми компаратива та суперлатива, відповідні аналітичні форми „мають порівняно незначне поширення в українській мові, їхнє вживання часто зумовлене впливом російської мови, для якої ці форми є типовими" 21. Вибір аналітичної форми переважно зумовлений іншомовним походженням

${ }^{15}$ Д. В. Рязанце в а, Прикметник сучасної української мови у вимірах граматики оияінки, автореф. дис. ... канд. філол. наук, Харків 2013.

${ }^{16}$ Там само, с. 11.

${ }^{17}$ Словотворчість незалежної України. 2012-2016. Словник, укл. А. Нелюба, С. Редько; заг. ред. А. Н елюб и, Харків 2017, с. 257.

${ }_{18}$ Там само, с. 258.

19 Д. В. Рязанцев а, Прикметник сучасної украӥнської мови у вимірах граматики очін$\kappa u . .$, c. 7 .

${ }^{20}$ В. 3. Санников, Русский язык в зеркале языковой игры,, Москва 2002, с. 158.

${ }^{21}$ Н. М. Ко с ту сяк, Категорія ступенів порівняння прикметників і прислівників, Луцьк 2001 , c. 30 . 
твірної основи, утрудненням структурно-морфологічних змін у похідному слові, складністю вимови тощо. Дослідники вже робили висновки про тенденції до зменшення частотності використання аналітичних форм ступенів порівняння прикметників 3 іншомовним походженням твірної основи ${ }^{22}$. У досліджуваному матеріалі зустрічаємо форму юніший (замість більш юний), порівн.: Навіщзо тобі я така... є жінки за мене юніші (М. Луговик-Синиця) ${ }^{23}$. Очевидно, при такому формотворенні, проявляючи лінгвокреативність, мовці й застосовують домінантну для української мови синтетичну модель утворення компаратива як репрезентант мовної свідомості етносу.

У словнику зафіксовано форми суперлатива від складних прикметників, утворених лексико-синтаксичним способом, порівн.: ...y “Джанто” цей епізод став смішною пародією, достойною найзубоскальнішої комедії (Український тиждень, 4/2013) ${ }^{24}$; У Японії існує найкотолюбніший офіс у світі (Українська правда, 18.01.2015) 25 . Як бачимо, складність вимови не зупиняє сучасного комуніканта в реалізації його мовотворчості для пошуку найточнішого змістового відтінку. Зауважимо також, що в численних прикладах утворенню ступеньованої форми передує моделювання прикметників-новотворів (андрійний, дедлайний, зубоскальний, кінотеатровий, котолюбний, неологізмний, солдатний), що на сьогодні словниками не зафіксовані.

Актуалізовані в сучасному мовленні й форми вищого та найвищого ступенів порівняння прикметників, що утворені від іменників з пропуском стадії прикметниковості. Такі утворення вже були в полі зору дослідників, які переконані, що „із позицій теорії дериваційних зв'язків такі похідні минають стадію прикметниковості й демонструють відносно елементарні формальні зв'язки, опосередковані проміжним (віртуальним, уявним) елементом, стадія утворення нульового ступеня порівняння в цьому разі відсутня" ${ }^{26}$. Продовжуємо простежувати традицію таких утворень (ляшкіший, москаліший, фашистіший, найетимологіший, найцицькіший), порівн.: Не станеш на прю ти - не гнутимеш прути і будеш білішим, але москалішим. Отож думай головою, як знов далі жити... (В. Простопчук); Коли я скидала ліфчик, він сказав: "Боже, мої найцицькіші друзі” (серіал “Теорія великого вибуху”). Подібні конструкції використовують для моделювання мовної гри, іронії, вираження оцінки.

Аналіз контекстуальних особливостей уживань форм суперлатива засвідчує їхнє частотне використання в тавтологічних словосполученнях, що дає змогу авторам висловлювань передати максимальний ступінь вияву ознаки, названої й прикметником, й іменником, тим самим змоделювати аксіологічні смисли, порівн.: найетимологічніший з етимологів; з усіх Андріїв найандрійніший Андрій; найдедлайніший дедлайн, найкінотеатровіші кінотеатри ${ }^{27}$. Навмисна смислова тотожність, що зумовлює мовну гру, забезпечує вираження значення надмірності ознаки, переважно для вербалізації позитивної оцінки.

${ }^{22}$ Д. В. Рязанцева, Ступені порівняння прикметників як ефективний засіб створення граматичного значення очінки (на матеріалі запозиченої лексики), [в:] „Вісник Дніпропетров. ун-ту. Серія «Мовознавство»”, відп. ред. Т. С. Пр и с т й ко, Дніпропетровськ 2011, № 11, вип. 17 , т. 2 , с. 160.

${ }^{23}$ Словотворчість незалежної Украӥни..., с. 449.

${ }^{24}$ Там само, с. 257.

${ }^{25}$ Там само.

${ }^{26}$ Д.В.Рязанце в а, Прикметник сучасної украӥнської мови у вимірах граматики оцін$\kappa и \ldots$, с. 11 .

${ }^{27}$ Словотворчість незалежної Украӥни..., с. 256-257. 
Помічаємо ще одну специфічну конструкцію з використанням компаратива, порівн.: Складається враження, що пан Каплін намагається бути ляшкішим за самого Ляшка (Утеодин з Майклом Щуром) ${ }^{28}$. По-перше, використана форма вищого ступеня порівняння утворена від іменника. У таких словах значення, передбачені компаративними відношеннями, не реалізуються, оскільки неможливим $є$ змістове співвіднесення 3 позитивним ступенем, тобто з нейтральною формою. Очевидно, таке співвіднесення відбувається зі значенням іменника. Іменнику, крім номінативної семи, властива певна якісна ознака, здатна ступенюватися. По-друге, напевно, у цьому разі (як і в описаній вище тавтологічній конструкції із суперлативом) ідеться про формування синтаксичного фразеологізму - конструкції, постійні компоненти якої пов'язані ідіоматично, створюють основу й “задають” загальне значення, проте заповнюються різним лексичним матеріалом, що й викликає формування певного конкретного значення, яке накладається на узагальнене. У таких моделях носієм найбільшого вияву ознаки є особа (предмет), названа іменником, проте змодельована форма компаратива передбачає більший іiі вияв, що й виражається відповідною фразеологізованою конструкцією. Аналогічні конструкції можна змоделювати від інших, наведених у словнику форм вищого ступеня порівняння, утворених від іменника, порівн.: фашистіший за самого фашиста; москаліший за самого москаля.

Раніше дослідники помітили „утворення форми суперлатива 3 пропуском так званої "середньої ланки” - форми компаратива, тобто перехід від звичайної форми прикметника одразу до найвищого ступеня" 29 : "Податки та бухгалтерський облік” - найбухгалтерська газета (з телереклами). У досліджуваному виданні словника інновацій такі новотвори не зафіксовано.

Як бачимо, з одного боку, мовлення сучасних українців відзначається лінгвокреативністю, індивідуалізацією, що реалізується у творчому підході до використання мовних засобів, з іншого - стандартизацією, яка засвідчує наявність стандартних моделей для мовотворчості, що як когнітивні структури зафіксовані в мовній свідомості. Інноваційне формотворення актуалізується завдяки наявностіпопередніх подібних уживань, що репрезентуються якпрецедент. У такий спосіб мовець у своєму мовленнєвому креативі слідує мовним настановам i “виправляє несправедливість" ${ }^{30}$, заповнюючи лакуни через відсутність готових засобів, доводячи мовну систему до умовної ідеальності, що мотивовано комунікативними потребами.

Спираючись на протиставлення норми й антинорми, Н. Арутюнова встановлює послідовність дії відхилення від норми, яка починається зі сприйняття світу, що надає відповідні відомості для комунікації, проходить через сферу спілкування, відбивається в лексичній, словотвірній і синтаксичній семантиці й завершується в словесній творчості ${ }^{31}$. При цьому норма $є$ універсальною категорією світобудови, що регулює ступінь порядку в хаосі. Однак виявити норму часто стає можливим лише завдяки фіксації відхилень від неї (,ненормативність допомагає виявити норму й правило"32). Проте інформативною, семантично навантаженою є саме аномалія як маркований корелят норми в опозиції норма - аномалія.

\footnotetext{
${ }^{28}$ Там само, с. 220.

29 Д.В.Рязанцев а, Прикметник сучасної украйнської мови у вимірах граматики оиінки..., с. 9.

${ }^{30}$ Б. Ю. Норман, Игра на гранях языка, Москва 2006, с. 38.

${ }^{31}$ Н. Д. Арутюнова, Аномалии и язык (к проблеме языковой “картины мира"), [в:] „Вопросы языкознания”, Москва 1987, № 3, с. 3-19.

${ }^{32}$ Н. Д. Арутюнова, Язык и мир человека, Москва 1999, с. 79.
} 
Аналіз зафіксованих в аналізованому словнику форм компаратива та суперлатива дає змогу констатувати, що виявлені моделі репрезентують сучасні тенденції відповідного формотворення. Для сучасної української мови типові утворення ступеньованих форм від якісних прикметників, що називають неградуйовану ознаку, від відносних та складних прикметників, а також іменників 3 пропуском стадії прикметниковості, тяжіння до синтетичних форм. Реалізовані моделі відзначаються регулярністю, відтворюючи традиційну граматичну стереотипність і породжуючи стереотипність у моделюванні додаткових смислів.

У процесі вивчення нових явищ сучасної української мови недостатньо обмежуватися констатуванням відступів від сформованих літературних норм. Тим більше з огляду на регулярну відтворюваність уже недоречно говорити про порушення мовних норм, навпаки, необхідно доповнити лінгвістичну літературу описами нових функцій мовних одиниць, коментарями щодо специфіки нових породжуваних значень. Виникає потреба в кодифікації відповідних тенденцій у граматиках української мови, фіксації й поясненні нових семантичних відтінків у лексикографічних джерелах.

\section{Список використаної літератури}

Апресян Ю. Д., Избр. тр., в 2 томах, т. 2, Интегральное описание языка и системная лексикография, Москва 1995.

Арутюнова Н. Д., Аномалии и язык (к проблеме языковой “картины мира”), [в:] „Вопросы языкознания”, Москва 1987, № 3, с. 3-11.

Арутюнова Н. Д., Язык и мир человека, Москва 1999.

Клименко Н. Ф., Карпіловська Є. А., Кислюк Л. П., Динамічні прочеси в сучасному украӥнському лексиконі, Київ 2008.

Колоїз Ж. В., Украӥнська оказіональна деривачія, Київ 2007.

Космеда Т. А., Лингвокалейдоскоп: процессы живой речи (на материале русского и украинского языков), Саарбрюккен 2017.

Космеда Т. А., Халіман О. В., Мовна гра в парадигмі інтерпретативної лінгвістики. Граматика оцінки. Граматична ігрема (теоретичне осмислення дискурсивної практики), Дрогобич 2013.

Костусяк Н. М., Категорія ступенів порівняння прикметників і прислівників, Луцьк 2001.

Лотман Ю. М., Декабрист в повседневной жизни (бытовое поведение как историко-психологическая категория), [в:] Литературное наследие декабристов, ред. В. Г. Базанов, В. Э. Вацуро, Ленинград 1975.

Матезиус В. О., О необходимости стабильности литературного языка, Москва 2003.

Норман Б. Ю., Игра на гранях языка, Москва 2006.

Ремчукова Е. Н., Аспекты и принщипы креативной грамматики, [в:] Теоретические проблемы функииональной грамматики, матер. Всерос. науч. конф., Санкт-Петербург 2001, c. 49-54.

Рязанцева Д., Порушення норми при ступенюванні прикметників, [в:] „Культура слова”, Київ 2011, вип. 74, с. 70-74.

Рязанцева Д. В., Прикметник сучасної украӥнської мови у вимірах граматики оиінки, автореф. дис. ... канд. філол. наук, Харків 2013.

Рязанцева Д. В., Ступені порівняння прикметників як ефективний засіб створення граматичного значення оцінки (на матеріалі сучасної української публіцистики), [в:] „Вісник Дніпропетров. ун-ту. Серія «Мовознавство»”, відп. ред. Т. С. Пристайко, Дніпропетровськ 2011, № 11, вип. 17, т. 2, с. 155-161.

Санников В. З., Русский язык в зеркале языковой игры, Москва 2002.

Словотворчість незалежної України. 2012-2016. Словник, укл. А. Нелюба, С. Редько; загальна ред. А. Нелюби, Харків 2017. 


\section{Spysok vykorystanoi literatury \\ [References]}

Apresyan Yu. D., Izbr. tr., v 2 tomah, t. 2, Integral'noe opisanie yazyka i sistemnaya leksikografiya [Integral Language Description and Systematic Lexicography], Moskva 1995.

Arutyunova N. D., Anomalii i yazyk (k probleme yazykovoj "kartiny mira" [Anomaly and Language (to the Problem of World Language Image)], [v:] „Voprosy yazykoznaniya”, Moskva 1987, № 3, s. 3-11.

Arutyunova N. D., Yazyk i mir cheloveka [Language and World of a Person], Moskva 1999.

Klymenko N. F., Karpilovska Ye. A., Kysliuk L. P., Dynamichni protsesy v suchasnomu ukrainskomu leksykoni [Dynamic Processes in Modern Ukrainian Lexicon], Kyiv 2008.

Koloiz Zh. V., Ukrainska okazionalna deryvatsiia [Ukrainian Occasional Derivation], Kyiv 2007.

Kosmeda T. A., Lingvokalejdoskop: processy zhivoj rechi (na materiale russkogo $i$ ukrainskogo yazykov) [Linguo-Kaleidoscope: Processes of Live Speech (on the Material of Russian and English)], Saarbryukken 2017.

Kosmeda T. A., Khaliman O. V., Movna hra v paradyhmi interpretatyvnoi linhvistyky. Hramatyka otsinky. Hramatychna ihrema (teoretychne osmyslennia dyskursyvnoi praktyky). [Language Game in Paradigm of Interpretation Linguistics. Grammar of Estimation. Grammatical Igramme (Theoretical Analysis of Discourse Practice)], Drohobych 2013.

Kostusiak N. M., Katehoriia stupeniv porivniannia prykmetnykiv i pryslivnykiv [Category of Degrees of Comparison of Adjectives and Adverbs], Lutsk 2001.

Lotman Yu. M., Dekabrist v povsednevnoj zhizni (bytovoe povedenie kak istorikopsihologicheskaya kategoriya) [Decabrist in Every-day Life (Mode of Life Behaviour as Psycological Category)], [v:] Literaturnoe nasledie dekabristov, red. V. H. Bazanov, V. E. Vaczuro, Leningrad 1975.

Matezius V. O., O neobhodimosti stabil'nosti literaturnogo yazyka [About the Necessity of Literary Language Stability], Moskva 2003.

Norman B. Yu., Igra na granyah yazyka [Game on Language Margins], Moskva 2006.

Remchukova E. N., Aspekty i principy kreativnoj grammatiki [Aspects and Principles of Creative Grammar], [v:] Teoreticheskie problemy funkcional'noj grammatiki, mater. Vseros. nauch. konf., Sankt-Peterburg 2001, s. 49-54.

Riazantseva D., Porushennia normy pry stupeniuvanni prykmetnykiv [Norm Violation in Degrees of Comparison of Adjectives], [v:] „Kultura slova”, Kyiv 2011, vyp. 74, s. 70-74.

Riazantseva D. V., Prykmetnyk suchasnoi ukrainskoi movy u vymirakh hramatyky otsinky [Adjectives of Modern Ukrainian Language through the Prism of Grammar of Estimation], avtoref. dys. ... kand. filol. nauk, Kharkiv 2013.

Riazantseva D. V., Stupeni porivniannia prykmetnykiv yak efektyvnyi zasib stvorennia hramatychnoho znachennia otsinky (na materiali suchasnoi ukrainskoi publitsystyky) [Degrees of Comparison of Adjectives as Effective Means of Formation of Grammatical Meaning of Estimation (based on the material of modern Ukrainian publicistics)], [v:] „Visnyk Dniprop. un-tu. Seriia «Movoznavstvo»”, vidp. red. T. S. Prystaiko, Dnipropetrovsk 2011, № 11, vyp. 17, t. 2, s. 155-161.

Sannikov V. Z., Russkij yazyk v zerkale yazykovoj igry [The Russian Language in Mirror of Language Play], Moskva 2002.

Slovotvorchist nezalezhnoi Ukrainy. 2012-2016 [Word-Formation of Independent Ukraine]. Slovnyk, ukl. A. Neliuba, Ye. Redko, zahalna red. A. Neliuby, Kharkiv 2017. 